\section{Ks. Grzegorz Rafiński}

Wyższe Seminarium Duchowne w Gdańsku g.rafi@wp.pl

DOI: http://dx.doi.org/10.12775/BPTh.2016.017

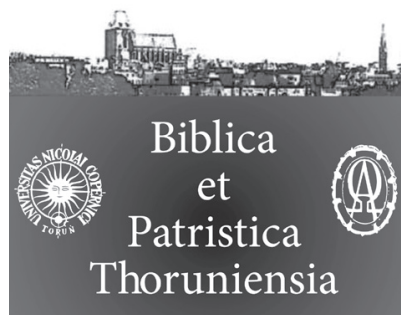

9 (2016) 2: 99-123

ISSN (print) 1689-5150

ISSN (online) 2450-7059

\title{
Św. Paweł o gościnności: między wielkodusznością i rozumem
}

\author{
St. Paul about hospitality: \\ between generosity and the mind
}

\begin{abstract}
Streszczenie. Z listów św. Pawła wynika wniosek, że gościnność była praktykowana wobec trzech grup ludzi: głosicieli Ewangelii (w tym św. Pawła), współ-chrześcijan i „obcych”, którzy nie należeli do Kościoła. Teksty źródłowe wskazują też na to, że gościnność miała granice. Gościnność była więc praktykowana w ramach, które streszcza podtytuł artykułu: „Między wielkodusznością i rozumem”. W tym kontekście autor artykułu wskazuje na cztery teksty z listów św. Pawła, w których zawarte są reguły wykonawcze dotyczące gościnności. Chrześcijan obowiązuje opcja na rzecz wielkoduszności, miłosierdzia ( $\mathrm{Rz} 15,7-12)$, która musi być weryfikowana przez rozum ( $\mathrm{Rz} 12,1-2)$. Decyzje chrześcijan muszą uwzględniać kontekst społeczno-polityczny (Rz 13,1-7), przy czym chrześcijanie powinni wnosić „wyższą sprawiedliwość” wynikająca z Ewangelii w realia ustalone przez władze państwowe (1 Kor 6,1-11). W końcowej części artykułu autor odnosi te reguły do problemu uchodźców.
\end{abstract}

Abstract. The conclusion that can be drawn from St. Paul's letters is that hospitality was practiced with regard to three groups of people: the preachers of the Gospel (including St. Paul), fellow-Christians and "others" who did not belong to the Church. Source texts also point to the fact that hospitality had the boundaries. Therefore, hospitality was practiced within the framework that is summarized by the article's subtitle: "Between generosity and the mind". In this context the author of the article points to four texts from St. Paul's letters, in which the implementing rules concerning hospitality are included. Christians are bound by the option toward generosity, charity (Romans 15:7-12) that has to be verified by the mind (Romans 12:1-2). The decisions of Christians have to take into account the socio-political context (Romans 13:1-7). At the same time Christians should implement "higher justice" resulting from the Gospel into reality settled by state authorities (1 Corinthians 6:1-11). In the final part of the article the author applies these rules to the problem of refugees.

Słowa kluczowe: gościnność; uchodźcy; św. Paweł.

Keywords: hospitality; refugees; St. Paul. 
$\mathrm{W}$ debacie, której temat przewodni brzmi: „Gościnność. Dla kogo? Perspektywa biblijna"1, nie może zabraknąć głosu św. Pawła, zwanego Apostołem narodów. Podtytuł niniejszego artykułu: „Między wielkodusznością i rozumem", sugeruje kierunek refleksji na temat gościnności zauważalny w Listach św. Pawła. Jak zobaczymy w toku artykułu, św. Paweł zaleca i wielkoduszność i rozwagę, z opcją na rzecz wielkoduszności, w granicach wyznaczanych przez fakt, że chrześcijanie podlegają równocześnie prawu cywilnemu i „wyższej sprawiedliwości” opartej na Ewangelii. Spojrzenie to należy zróżnicować, odnosząc je do trzech kręgów adresatów gościnności: do głosicieli Ewangelii, do współ-chrześcijan i do „obcych”. Tematowi gościnności nadaje szczególnego dramatyzmu problem uchodźców, do którego odniesiemy się na podstawie przesłanek zawartych w Listach św. Pawła w końcowej części artykułu

\section{Teksty źródłowe dotyczące gościnności i postawienie problemu}

Wskazanie tekstów źródłowych dotyczących gościnności może ułatwić pewna dygresja historyczna związana ze słowem „ksenodochium”, które pochodzi z języka greckiego. Ksenodochium to budynek, w którym mogli zatrzymywać się wędrowcy, a także chorzy, otrzymując darmowo dach nad głową, wyżywienie i opiekę . Taki obiekt został na przykład zbudowany przez cystersów w połowie XVIII wieku w parafii w Łęgowie. Choć kasata cystersów sprawiła, że przeznaczenie tego obiektu zmieniło się, to jest on istniejącym do dzisiaj świadectwem gościnności cystersów ${ }^{3}$. W tymże samym Łęgowie, we wnętrzu kościoła, znajduje się z kolei wcześniej powstały obraz zatytułowany „Wrogowie krzyża”, który zaprzecza idei gościnności i wskazuje na obawy przed „obcymi”. Do „wrogów krzyża” (słowa: „Inimici Crucis Christi” są wypisane w centrum obrazu), którzy próbują obalić krzyż, na którym wisi Chrystus, autor obrazu zaliczył Turka, rajtara szwedzkiego i pastora protestanckiego. To „obcy”, wi-

1 Jest to temat sympozjum zorganizowanego na UMK w Toruniu w dniu 19 maja 2016 roku.

2 Notabene, papież Franciszek zachęcał parafie do organizowania podobnych miejsc dla emigrantów.

3 Przed budynkiem byłego ksenodochium w Łęgowie znajduje się tablica z następującym opisem: „Był to dom, w którym mogli się schronić pielgrzymi, wędrowcy i bezdomni, otrzymując za darmo nocleg i pożywienie oraz «dom ulgi w cierpieniu», w którym roztaczano opiekę nad chorymi. Potrzebom podopiecznych służył przylegający do domu ogród. Dom ten zbudował w 1749 roku o. Iwo Roweder (1699-1765), przeor klasztoru cysterskiego w Oliwie w latach 1738-1754, proboszcz parafii w Łęgowie i w Różynach w latach 1741-1765 , pochowany w kościele w Łęgowie”. 
dziani jako agresorzy zagrażający tożsamości członków Kościoła Katolickiego ${ }^{4}$. Oba te obiekty są doskonałą ilustracją problemu zarysowanego w podtytule niniejszego artykułu: „między wielkodusznością i rozwagą”.

W jakich tekstach św. Pawła jest mowa o gościnności? W słowie „ksenodochium” pobrzmiewają terminy greckie, które w NT odnoszą się właśnie do gościnności:

1) $\phi \iota \lambda \circ \xi \in \nu i ́ \alpha$ (2 razy w NT): "gościnność, miłość do tego, co obce"; Rz 12,13; Hbr 13,2. Także $\xi \in \nu^{\prime} \alpha$ : „gościna”; Flm 22.

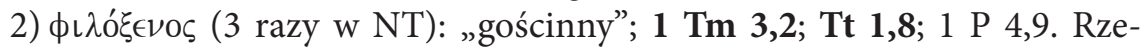
czownik $\xi^{\prime} \in \nu \circ \varsigma$ oznacza też gospodarza domu udzielającego gościny (Rz 16,23).

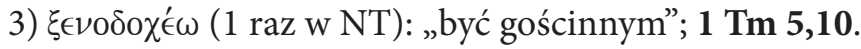

4) $\xi \in \nu \imath \zeta \omega$ (10 razy w NT, nie występuje w Corpus Paulinum): „przyjąć w dom, dać zamieszkanie”; Dz (7 razy), Hbr (1 raz), 1 P (2 razy).

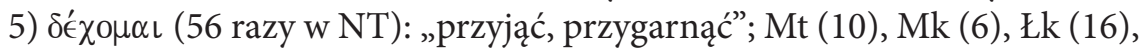
J (1), Dz (8); 1 Kor (1), 2 Kor (5), Ga (1), Ef (1), Flp (1), Kol (1), 1 Tes (2), 2 Tes (1), Hbr (1), Jk (1); 2 Kor 7,15; 2 Kor 11,16; Ga 4,14; Kol 4,10.

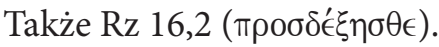

Z tematyką gościnności łączą się też terminy określające „obcych”: Ef 2,19:

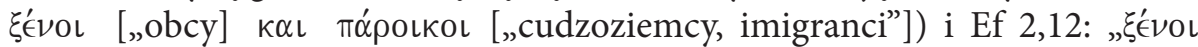
[”obcy” = „nie-Żydzi”, „cudzoziemcy”] wobec społeczności Izraela”.

Powyżej wskazane teksty źródłowe odnoszą się do trzech kręgów adresatów gościnności: głosicieli Ewangelii (w tym Pawła), współ-chrześcijan i „obcych”.

Z gościnnością łączą się też teksty, w których św. Paweł radzi, aby zacho-

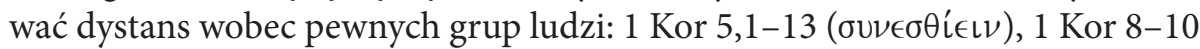

4 „Scena na obrazie rozgrywa się na górze. W centrum znajduje się krzyż, na którym został rozpięty Chrystus. Postacie tego przedstawienia można podzielić na dwie grupy: na wiernych - katolików i innowierców. Pod krzyżem stoi grupa mężczyzn, ubranych w szaty typowe dla XVII wieku, turbany, kapelusze. Są ukazani jednocześnie jako różnowiercy i obcokrajowcy. Wśród nich można rozróżnić między innymi Szwedów i Turków. Poszczególne postacie usiłują zniszczyć i obalić krzyż, używając między innymi haków, siekier oraz piły. Od prawej strony obrazu, przy krzyżu klęczy Turek w ciemnym żupanie, z turbanem na głowie, trzymając długą piłę, której drugi koniec trzyma szwedzki rajtar, znajdujący się po lewej stronie obrazu. [...] Postacią po drugiej stronie krzyża, wbijającą w niego siekierę, zdaje się być luterański pastor, ubrany w czarną togę z barokową białą kryzą na szyi popularną w drugiej połowie XVI i XVII wieku. [...] Na drugim planie, z lewej strony obrazu, stoi katolicki duchowny, w białej szacie, rozkładający bezradnie ręce. Kaznodziei towarzyszą wierni. Nad księdzem po lewej wyłania się z chmur ręka trzymająca krzyż. Całość obrazu poza postaciami wypełnia niebo, przesłonięte chmurami, które rozstępują się tylko nad Chrystusem" (H. Jakubowska, Obraz «Wrogowie Krzyża» w kościele pw. św. Mikołaja w Łęgowie, s. 15-16). 
(problem zasiadania do stołu z poganami), 2 Kor 6,14; Ga 1,6.9; 3,10; Flp 3,2-3; 2 Tes 3,6.

W refleksji nad gościnnością należy uwzględnić cztery teksty, w których zawarte są reguły wykonawcze: Rz 15,7-12; Rz 12,1-2; Rz 13,1-7; 1 Kor 6,1-11.

Teksty źródłowe pozwalają na postawienie problemu, który zawiera się w następujących pytaniach: Wielkoduszność? Rozwaga? A może jedno i drugie - z opcją na rzecz wielkoduszności (w granicach wyznaczanych przez fakt, że chrześcijanie podlegają równocześnie dwóm porządkom: prawu państwowemu i „wyższej sprawiedliwości” ewangelicznej)?

\section{Wielkoduszność wobec gości}

Jak zaznaczyliśmy powyżej, można rozróżnić trzy kręgi adresatów gościnności. Dotyczy ona głosicieli Ewangelii, współ-chrześcijan i „obcych”.

\subsection{Gościnność wobec głosicieli Ewangelii}

Gościnność jest powinnością chrześcijan w odniesieniu do głosicieli Ewangelii ${ }^{5}$. Sam św. Paweł korzystał wielokrotnie z gościnności tych, którym głosił Ewangelię. Świadectwem serdecznych więzi, jakie wytwarzały się między Pawłem i wiernymi udzielającymi mu gościny, jest przejmujący opis pożegnania Pawła z Efezjanami, opisany w Dziejach Apostolskich: Paweł „upadł na kolana i modlił się razem ze wszystkimi. Wtedy wszyscy wybuchnęli wielkim płaczem. Rzucali się Pawłowi na szyję i całowali go, smucąc się najbardziej z tego, co powiedział: że już nigdy go nie zobaczą. Potem odprowadzili go na okręt" (Dz 20,36-38). W Dziejach Apostolskich jest więcej opisów gościnności wobec Pawła (Dz 9,10-20; 16,14n; 17,5-7; 18, 7.27; 21,4-6.8.16; 28,7), a także wobec Piotra (Dz 9,6.18.32.48).

W Liście do Galatów Paweł pisze o wielkiej gościnności, której doświadczył w Galacji: „Wiecie przecież, jak pierwszy raz głosiłem wam Ewangelię zatrzymany chorobą i jak mimo próby, na jaką moje niedomagania cielesne was wystawiło, nie wzgardziliście mną ani nie odtrąciliście, ale mnie przyjęliście

5 Motyw ten jest obecny także w tradycji Janowej. W 3 J 5-8 znajduje się wezwanie do gościnności wobec misjonarzy, zaś w $2 \mathrm{~J}$ 10n - zakaz udzielania gościny nauczycielom fałszu (2 J 10n). 


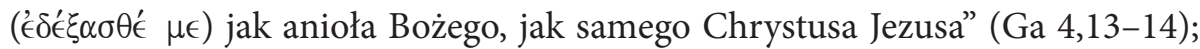
"gdyby to było możliwe, bylibyście sobie oczy wydarli i dali je mnie" $(\mathrm{Ga} 4,15)^{6}$.

W Liście do Rzymian św. Paweł poleca przyjąć w gościnę Febę (Rz 16,1-2:

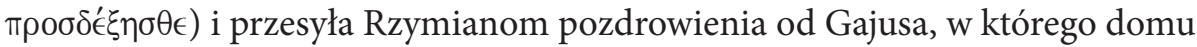
(w Koryncie) właśnie zaznaje gościny (Rz 16,23).

Gościnności wiernych doświadczył Tytus, o czym Paweł pisze w Drugim Liście do Koryntian: „prawdziwą jest nasza chluba wobec Tytusa. Serce zaś jego jeszcze bardziej lgnie ku wam, gdy wspomina wasze posłuszeństwo i to, jak przyjęliście go $\left({ }^{\prime} \epsilon^{\prime} \in \xi^{\prime} \alpha \sigma \theta \epsilon\right)$ z bojaźnią i drżeniem. Cieszę się, że we wszystkim mogę wam ufać" $(2$ Kor 7,15$)$. Paweł wyraża nadzieję na gościnność Koryntian, gdy do nich przybędzie: „Jeszcze raz mówię: niech mnie nikt nie uważa za

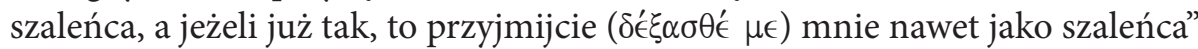
(2 Kor 11,16). W Liście do Kolosan Paweł pisze, że oczekuje od Kolosan gościnnego przyjęcia Marka: „Pozdrawia was Arystarch, mój współwięzień, i Marek, kuzyn Barnaby, co do którego otrzymaliście zlecenia: Przyjmijcie ( $\left.\delta^{\prime} \xi \alpha \sigma \theta \epsilon\right)$ go, jeśli do was przybędzie" (Kol 4,10).

Paweł wspomina także serdeczne przyjęcie, jakiego doznał w Tesalonice $(1$ Tes 1,9$)$.

Gościnność, której doświadczał Paweł i jego towarzysze wpisuje się w szerszą strategię misyjną $a^{7}$

a) Paweł kierował się wyłącznie do miast.

b) Wśród odwiedzanych miast wybierał jako „bazy” większe miasta, ważne z punktu widzenia komunikacyjnego i dlatego otwarte na nowe idee;

6 List do Galatów stanowi reakcję Pawła na odejście Galatów od jego nauczania na skutek agitacji przeciwników wywodzących się z kręgu chrześcijan „judaizujących”, którzy głosili, że do usprawiedliwienia nie wystarcza sama tylko wiara w Jezusa Chrystusa, jak głosił Paweł, ale konieczne jest także (!) „stanie się Żydem”. Nakłaniali oni do praktykowania trzech „uczynków”, które stanowiły o statusie „bycia Żydem”: do obrzezania i do praktykowanie żydowskich przepisów pokarmowych i kalendarza żydowskiego. Paweł przypomniał w liście swe pierwotne nauczanie o usprawiedliwieniu z wiary w Chrystusa, a nie przez wypełnianie Prawa za pomocą uczynków (Ga 2,16), zaś wspomnienie gościnności Galatów wykorzystał jako jeden z argumentów mających nakłonić ich do zdystansowania się od nauczania jego przeciwników. Ga 4,12-20 jest jednym z argumentów na rzecz propositio zawartej w Ga 2,16 i mieści się w następującym toku wynikania (strukturze) Listu do Galatów: I. Wstęp epistolarny (1,1-5); II. Exordium (1,6-9); III. Narratio $(1,10-2,13)$; IV. Propositio (2,16 w 2,14-3,5); V. Probatio (3,6-5,12): 1) Abraham (3,6-4,11); 2) Wspomnienie serdecznego przyjęcia Pawła przez Galatów (4,12-20); 3) Alegoria Sary i Hagar $(4,21-5,1)$; 4) Doświadczenie wolności chrześcijańskiej (5,2-12); VI. Exhortatio (5,13-6,10); VII. Zakończenie epistolarne (6,11-18). Por. J. Smit, The Letter of Paul to the Galatians. A deliberative Speech, s. 1-26.

7 Por. G. Barbaglio, Paolo di Tarso e le origini cristiane, s. 96-103. 
odwiedza te miasta wielokrotnie (w Antiochii Paweł rozpoczynał I, II i III podróż misyjną i kończył I i II podróż, a w Tesalonice, Koryncie i Efezie przebywał kilkakrotnie podczas II i III podróży misyjnej). Mając na uwadze strategię apostolską św. Pawła można by w jego usta włożyć następujący plan: „Muszę udać się do Antiochii, bo to jest miasto łączące Daleki Wschód z Azją Mniejszą, w którym przecinają się szlaki karawan; muszę dotrzeć do Efezu, bo jest to wielki port Azji, do Tesaloniki, bo jest to brama do Macedonii, do Koryntu, bo tam Morze Egejskie łączy się z Adriatykiem i do Rzymu - bo jest to serce Imperium".

c) Wybierał miasta, które nie były jeszcze przez nikogo ewangelizowane, gdyż chciał tworzyć nowe wspólnoty wierzących.

d) Od samego początku czuł się powołanym do zaniesienia Ewangelii poganom, mając plany misyjne obejmujące cały znany mu świat: nie tylko Wschód, ale i Zachód (Rzym: Rz 1,15; Hiszpania: Rz 15,23-24.28).

e) Celem Pawła nie było nawracanie jednostek, ale tworzenie struktur w miejskich wspólnotach, które miały promieniować na okolicę.

f) Nie wykluczał żadnego ludu jako adresata Ewangelii, przełamywał podziały między ludźmi, pragnąc tworzyć jeden lud Boży.

Dla osiągnięcia tych celów św. Paweł musiał przewidzieć pewne kroki logistyczne ${ }^{8}$ : dotarcie do zamierzonej miejscowości ${ }^{9}$, znalezienie dachu nad głową, poszukanie miejsc nadających się do głoszenia Ewangelii, pozyskanie pomocników i środków finansowych. W realizacji tych posunięć logistycznych ważną rolę spełniało korzystanie z gościnności wiernych, którzy oddawali do jego dyspozycji swe domy. W poszukiwaniu dachu nad głową w mieście docelowym św. Paweł korzystał ze znajomości, nocując u przyjaciól, których wcześniej spotkał, ale też zatrzymywał się w noclegowniach przy synagogach (nie nocował w budynkach publicznych). Na miejsce głoszenia Ewangelii wybierał synagogi (jako Żyd miał prawo zabierać głos podczas nabożeństw), a także domy przyjaciól, sympatyków i neofitów. Domy były dobrym miejscem kontaktowym ze środowiskiem rzemieślników (Paweł pracował przecież własnymi rękami) i z gośćmi gospodarzy domu ${ }^{10}$. Z Pawłem współpracowały setki osób,

8 Por. G. Barbaglio, op. cit., s. 103-108.

9 Paweł przemierzył przynajmniej dziesięć tysięcy mil, korzystając z bitych dróg rzymskich, nad bezpieczeństwem których czuwały posterunki rzymskie i przy których były miejsca noclegowe. Korzystał też z podróży morskich, które były dobrze zorganizowane. Zimą, z powodu wiatrów, morza były zamknięte dla podróżnych (mare clausum). Sezon żeglugowy zaczynał się na wiosnę, w święto ku czci Izydy (navigium Isidis).

10 Pamiętać trzeba, że w starożytności „dom” był dużą strukturą zamieszkała niekiedy przez kilkadziesiąt osób, gdyż obejmował nie tylko mieszkania dla członków rodziny, ale także pomieszczenia dla niewolników, gości i rzemieślników. 
z których niektórzy towarzyszyli mu w podróżach ${ }^{11}$. Paweł prowadził szeroką działalność bardzo skromnymi środkami finansowymi. Potrzebne środki finansowe pozyskiwał swoją pracą ${ }^{12}$. Korzystał też z pomocy finansowej Kościołów (2 Kor 11,8-9; Flp 4,15-16). Polecał, aby w miejscach, które odwiedzi przygotować wszystko konieczne (Rz 15,24; 1 Kor 16,6.11; 2 Kor 1,16).

$\mathrm{Z}$ pozytywnym obrazem relacji między wiernymi i tymi, którzy głosili im Ewangelię, kontrastuje ostrzeżenie (ciągle aktualne!) zawarte w 1 Kor 3,5-23. Św. Paweł zwraca się do wiernych z Koryntu, którzy dali się zawłaszczyć przez poszczególnych głosicieli Ewangelii, co spowodowało podziały we wspólnocie Kościoła: „Wszystko bowiem jest wasze: czy to Paweł, czy Apollos, czy Kefas; czy to świat, czy to świat, czy życie, czy śmierć, czy to rzeczy teraźniejsze, czy przyszłe; wszystko jest wasze, wy zaś Chrystusa, a Chrystus - Boga” (1 Kor 3,21-23). Wierni nie należą do głosicieli Ewangelii, ale to głosiciele Ewangelii są sługami wiernych.

\subsection{Gościnność wobec współ-chrześcijan i wobec „obcych”}

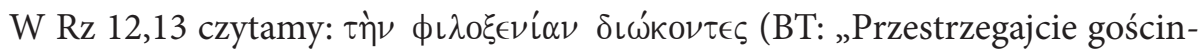
ności”). Jest to jedyne użycie rzeczownika $\phi \iota \lambda o \xi \in \nu i \alpha$ w Listach św. Pawła ${ }^{13}$ (notabene, rozpoznajemy $\mathrm{w}$ słowie $\phi \iota \lambda o \xi \in \nu i \alpha$ brzmienie terminu występującego

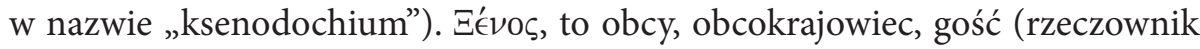
$\xi \in \nu^{\prime} \alpha$ oznacza miejsce dla przyjęcia gości, a czasownik $\xi \in \nu i \zeta \omega-$ akt przyjęcia

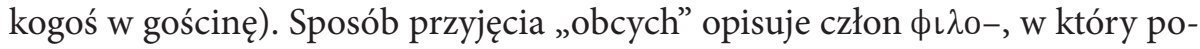
brzmiewa rzeczownik $\phi i ́ \lambda$ os oznaczający przyjaciela oraz czasownik $\phi \iota \lambda \epsilon ́ \omega$ opisujący relację miłości, głębokiego uczucia, a także jego uzewnętrznienie przez pocałunek. W sumie, słowo $\phi \iota \lambda \circ \xi \in \nu i \alpha$ określa relację absolutnie pozytywną,

11 Pierwszym towarzyszem Pawła był Barnaba. W adresach listów są wymienieni: Sostenes (1 Kor 1,1), Tymoteusz (2 Kor 1,1; Flp 1,1; Kol 1,1; 1 Tes 1,1, 2 Tes 1,1), Sylwan (1 Tes 1,1; 2 Tes 1,1). Inni współpracowali z nim w założonych Kościołach. W Filippi byli to: Ewodia, Syntycha, Syzyg i Klemens (Flp 4,2-3). W Koryncie: Chloe (1 Kor 1,11), Stefanas (1 Kor 16,15) i inni. Szerokie „znajomości” ujawnia Paweł w Rz 16,1-24. Wymienia tam współpracowników, tych, których znał osobiście w Rzymie i w innych miastach. Paweł wymienia: Febę, Pryskę, Akwilę, Epeneta, Marię, Andronika, Juniasa, Ampliata, Urbana, Stachysa, Apellesa, Arystobula, Herodiana, Narcyza, Tryfenę, Tryfozę, Persyda, Rufusa, Asynkryta, Flegonta, Hermesa, Patrobę, Hermasa, Filologa, Julię, Nereusza, Olimpasa, Tymoteusza, Lucjusza, Jazona, Sozypatera, Tercjusza, Gajusa, Erasta i Kwartusa.

12 Zob. G. Szamocki, Święty Pawet rzemieślnik, w: Życie, apostolat i dziedzictwo Pawła $z$ Tarsu, s. 64-74.

13 Oprócz tego w NT słowo $\phi\llcorner\lambda o \xi \in v i ́ \alpha$ jest użyte w Hbr 13,2. Dwukrotnie występuje

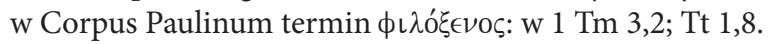




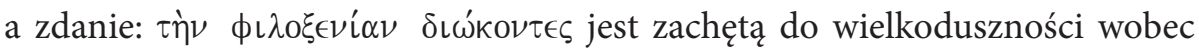
„obcych".

Na ustalenie kręgu adresatów gościnności w Rz 12,13 rzuca światło kontekst bliższy, którym jest perykopa obejmująca Rz 12,9-21 mająca następującą strukturę:

a) Teza: „Miłość niech będzie bez obłudy” (Rz 12,9). Praktykowanie gościnności jest jedną z oznak miłości „bez obłudy”. Tam, gdzie kończy się miłość, rozpoczyna się obłuda, hipokryzja.

b) Aplikacja tezy do relacji między chrześcijanami (Rz 12,9b-16): „Miejcie wstręt do złego, podążajcie za dobrem! W miłości braterskiej nawzajem bądźcie życzliwi! W okazywaniu czci jedni drugich wyprzedzajcie! Nie opuszczajcie się w gorliwości! Bądźcie płomiennego ducha! Pełnijcie służbę Panu! Weselcie się nadzieją! W ucisku bądźcie cierpliwi, w modlitwie - wytrwali! Zaradzajcie potrzebom świętych! Przestrzegajcie gościnności! Błogosławcie tych, którzy was prześladują! Błogosławcie, a nie złorzeczcie! Weselcie się z tymi, którzy się weselą, płaczcie z tymi, którzy płaczą. Bądźcie zgodni we wzajemnych uczuciach! Nie gońcie za wielkością, lecz niech was pociąga to, co pokorne! Nie uważajcie sami siebie za mądrych!". Znakiem rozpoznawczym wierzącego w Ewangelię jest miłość wobec współ-chrześcijan („braci”, „swiętych”) przejawiająca się między innymi przez gościnność.

c) Aplikacja tezy do relacji z niewierzącymi (Rz 12,17-21): „Nikomu złem za złe nie odpłacajcie. Starajcie się dobrze czynić wobec wszystkich ludzi! Jeżeli to jest możliwe, o ile to od was zależy, żyjcie w zgodzie ze wszystkimi ludźmi! Umiłowani, nie wymierzajcie sami sobie sprawiedliwości, lecz pozostawcie to pomście [Bożej]! Napisano bowiem: Do Mnie należy pomsta. Ja wymierzę zapłatę - mówi Pan - ale: Jeżeli nieprzyjaciel twój cierpi głód - nakarm go. Jeżeli pragnie - napój go! Tak bowiem czyniąc, węgle żarzące zgromadzisz na jego głowę. Nie daj się zwyciężyć złu, ale zło dobrem zwyciężaj!” Oczyszczanie miłości z obłudy wymaga miłości nie tylko wobec współ-chrześcijan, ale też wobec nieprzyjaciół, niewierzących, „wszystkich ludzi” (Rz 12,17.18). Dwukrotnie określa Paweł podobną zasadę: nie należy odpłacać złem za zło, ale trzeba czynić wszystkim dobrze (w.17), odpłacać dobrem za zło, aby w ten sposób nawrócić czyniących zło: zło dobrem zwyciężyć (w. 19b-21). Chrześcijanie powinni dążyć do zgody ze wszystkimi ludźmi, zrezygnować z zemsty. Ostatnie zdanie perykopy: „Nie daj się zwyciężyć złu, ale zło dobrem zwyciężaj” stanowi podkreślenie myśli z w. 19b-20, ale też podsumowanie całej perykopy: „Każde pokonanie siebie, złamanie własnego egoizmu, odpłacenie dobrem za niewdzięczność - to zdecydowane tryumfy dobra nad złem, to wyraźne umniejszenie się zła w świecie. Tylko miłość niesie ze sobą życie. Zło jest 
największym wrogiem życia"14. W ten kontekst wpisuje się wymóg gościnności zapisany w Rz 12,13.

Z Listów pasterskich wynika, że gościnnością powinni się cechować szczególnie biskupi, a także wdowy:

- „Biskup więc powinien być nienaganny, mąż jednej żony, trzeźwy, roz-

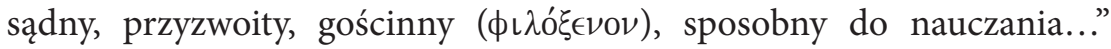
(1 Tm 3,2).

- „Biskup bowiem winien być [...], jako włodarz Boży, człowiekiem nienagannym, niezarozumiałym, nieskłonnym do gniewu, nieskorym do pijaństwa i awantur, nie chciwym brudnego zysku, lecz gościnnym ( $\phi \iota \lambda \hat{o}$

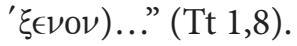

- „Do spisu należy wciągnąć taką wdowę, która ma co najmniej lat sześćdziesiąt, była żoną jednego męża, ma za sobą świadectwo o [takich] do-

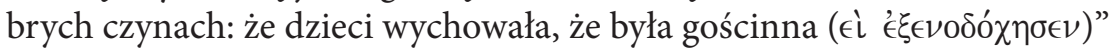
(1 Tm 5,10).

Z opisanego powyżej przeglądu tekstów źródłowych wynika, że gościnność jest generalnym wymogiem życia chrześcijańskiego ( $\mathrm{Rz} 12,13)$. Jest szczególną powinnością szczególnie biskupów i wdów. Cechowali się nią adresaci 2 Kor (w odniesieniu do samego Pawła i Tytusa) i adresaci Ga (w stosunku do Pawła). Jest zalecana przez Pawła adresatom 2 Kor (w stosunku do niego samego) i adresatom Kol (w relacji do Marka). „Adresatami” gościnności są nie tylko współ-chrześcijanie, ale „wszyscy ludzie” (Rz 12,17-21).

\section{Granice gościnności}

Wielkoduszna gościnność może być niekiedy zawieszona. Postępowanie chrześcijan jest w każdym przypadku podporządkowane postulatowi rozumnej oceny rzeczywistości - nie może być bezkrytyczne. Zalecenie gościnności domaga się osobistego przepracowania, osądu. Perykopa Rz 12,9-21 łączy się

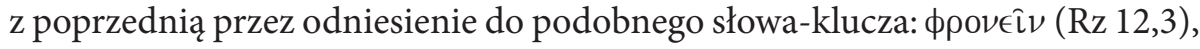

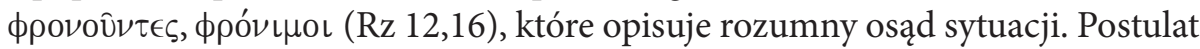

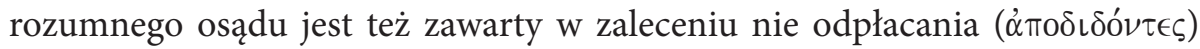
złem za zło, zapisanym w Rz 12,17, które łączy terminologicznie Rz 12,9-21

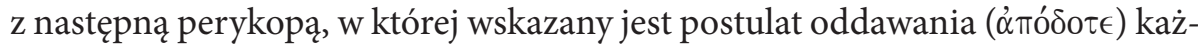
demu, co mu się należy (Rz 13,7). Przez tekst przewija się więc motyw rozumnej oceny rzeczywistości, która ma poprzedzić działanie chrześcijanina (zob.

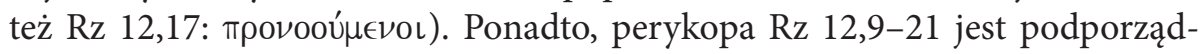

14 K. Romaniuk, List do Rzymian. Wstęp - przekład z oryginału. Komentarz, s. 249. 
kowana tezie zawartej w Rz 12,1-2, w której Paweł wskazuje, że rozum jest źródłem wartości moralnej czynu ludzkiego ${ }^{15}$.

W Listach do Koryntian znajdują się zalecenia Pawła, aby w pewnych przypadkach ograniczyć gościnność.

W 2 Kor 6,14 Paweł każe zdystansować się w pewnych przypadkach od niewierzących: „Nie wprzęgajcie się z niewierzącymi w jedno jarzmo”. Nie chodzi jednak o generalne odcięcie się od niewierzących, o czym świadczy 1 Kor 5,9-13. Paweł wyklucza ze wspólnoty stołu chrześcijanina, który dopuścił się publicznego grzechu określonego jako порvєí $\alpha$, a także tych chrześcijan, którzy są „rozpustnikami”: „Napisałem wam w liście, żebyście nie obcowali z rozpustnikami. Nie chodzi o rozpustników tego świata $\mathrm{w}$ ogóle ani o chciwców i zdzierców lub bałwochwalców; musielibyście bowiem całkowicie opuścić ten świat. Dlatego pisałem wam wówczas, byście nie przestawali z takim, który nazywając się bratem, w rzeczywistości jest rozpustnikiem, chciwcem, bałwochwalcą, oszczercą, pijakiem lub zdziercą. $\mathbf{Z}$ takim nawet nie siadajcie wspólnie do posiłku ( $\mu \eta \delta^{\prime} \epsilon$ $\left.\sigma \nu \nu \in \sigma \theta i \in \epsilon \nu\right)$. Jakże bowiem mogę sądzić tych, którzy są na zewnątrz? Czyż i wy nie sądzicie tych, którzy są wewnątrz? Tych, którzy są na zewnątrz, osądzi Bóg. Usuńcie złego spośród was samych”. Szczególnie ważne są dwa wiersze kończące perykopę zawartą w 1 Kor 5,1-13, które wskazują, że chrześcijan obowiązuje tolerancja wobec postępowania „tych, którzy są na zewnątrz [Kościoła]” i nie tolerowanie zła wewnątrz Kościoła, u „tych, którzy są wewnątrz”, co wynika z następującej sekwencji pytań i odpowiedzi:

- pytanie 1 (w. 12a): „Jakże bowiem mogę sądzić tych, którzy są na ze-

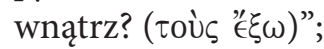

- odpowiedź na pytanie 1 (w. 13a): „Tych, którzy są na zewnątrz, osądzi Bóg";

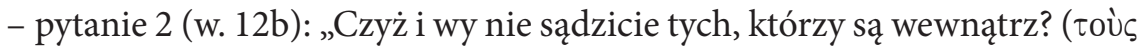
"€ $\sigma \omega)$ ";

- odpowiedź na pytanie 2 (w. 13b): „Usuńcie złego spośród was samych” (cytat z: Pwt 13,6; 17,7; 19,19; 22,24).

Wezwanie do nietolerancji wobec zła w Kościele nie jest ostatnim słowem Pawła. W Rz 14 znajduje on powody do tolerancji wobec słabości współ-chrześcijan (zob. Rz 14,15.19.22-23), aż po stwierdzenie w Rz 15,7: „przygarniajcie siebie nawzajem".

15 Por. G. Rafiński, Rozum jako źródło wartości moralnej czynu ludzkiego w Liście św. Pawta do Rzymian, s. 335-357. 
Z gościnnością łączy się też tematyka 1 Kor 8-10. Paweł zaleca rezygnację $\mathrm{z}$ zasiadania do stołu z poganami na ucztach, podczas których spożywano pokarmy składane w ofierze bożkom.

W Liście do Galatów Paweł „ekskomunikuje”, wyklucza ze wspólnoty (także z grona objętego gościnnością) głosicieli „innej Ewangelii” (Ga 1,6): „Gdyby wam kto głosił Ewangelię różną od tej, którą [od nas] otrzymaliście - niech będzie przeklęty"; Ga 1,9). Wyklucza też tych chrześcijan, którzy ulegli propagandzie fałszywych nauczycieli: „Na tych wszystkich, którzy polegają na uczynkach Prawa, ciąży przekleństwo" (Ga 3,10).

W Liście do Filipian znajduje się podobne ostrzeżenie wyrażone w bardzo mocny sposób: „Strzeżcie się psów, strzeżcie się złych pracowników, strzeżcie się okaleczeńców! My bowiem jesteśmy prawdziwie ludem obrzezanym - my, którzy sprawujemy kult w Duchu Bożym i chlubimy się w Chrystusie Jezusie, a nie pokładamy ufności w ciele" (Flp 3,2-3). Paweł ostrzega Filipian przed swoimi przeciwnikami, którzy głosili, „że aby korzystać z przywilejów Izraela, $\mathrm{z}$ obietnic danych przez Boga ludowi wybranemu, należy praktykować rytuał obrzezania"16.

W 2 Tes, rozważając problem postawy chrześcijan oczekujących na Paruzję, Paweł nakazuje wykluczenie niektórych chrześcijan ze wspólnoty (także z grona objętego gościnnością): „Nakazujemy wam, bracia, w imię Pana naszego Jezusa Chrystusa, abyście stronili od każdego brata, który postępuje wbrew porządkowi, a nie według tradycji, którą przejęliście od nas" (2 Tes 3,6$)$. Chodzi o chrześcijan, do których Paweł kieruje upomnienie: „Kto nie chce pracować, niech też nie je" (2 Tes 3,10).

\section{Między wielkodusznością i rozumem: reguły wykonawcze dotyczące gościnności}

Jakie reguły wykonawcze wskazuje św. Paweł? Odpowiedź na to pytanie znajdują się w czterech tekstach św. Pawła, w Rz 15,7-12, w Rz 12,1-2, w Rz 13,1-7 i w 1 Kor 6,1-11. Współzależność tych tekstów ukazuje poniższy schemat:

16 Por. P. Ortiz, List do Filipian, s. 1542. 


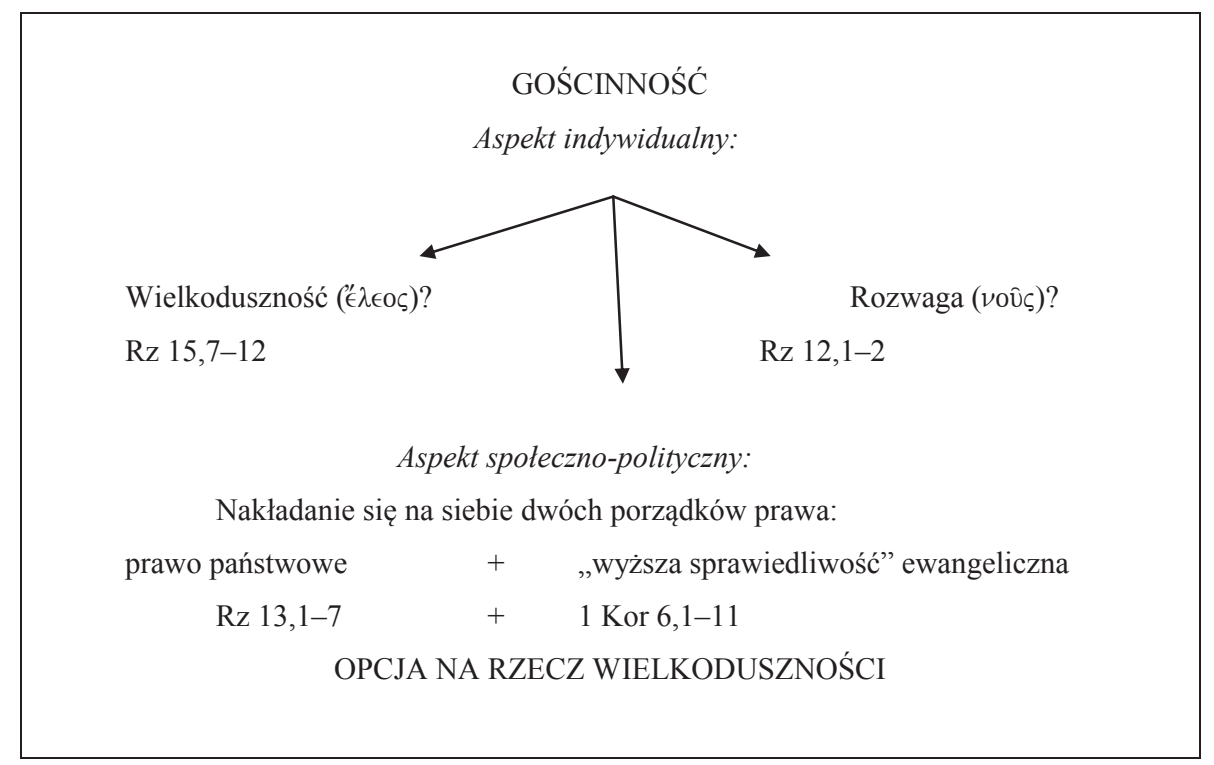

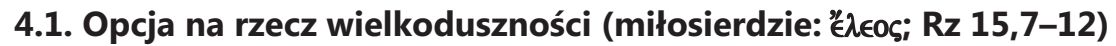

Rz 15,7-12 jest kluczowym tekstem dla zrozumienia całego nowotestamentowego orędzia na temat gościnności. Jak pisze Wolfgang Winter: „W NT zostało podjęte starotestamentowe pytanie o jej (gościnności: przyp. GR) podstawę: ponieważ Chrystus "przyjął» ludzi, przeto mogą i powinni również oni wzajemnie się «przyjmować» (Rz 15,7nn.)" ${ }^{17}$.

Z Rz 15,7-12 wynika, że chrześcijan obowiązuje wielkoduszna gościnność. Świadomość tego, że otrzymujemy zbawienie dzięki miłosierdziu Boga („Chrystus przygarnął was - ku chwale Boga”), ma być motywacją do wzajemnego przygarniania się $(15,7)$. Wielkoduszna gościnność jest, generalnie, obowiązkiem chrześcijan. Motywacja gościnności jest wskazana w Rz 15,7-12:

„Dlatego przygarniajcie się nawzajem, bo i Chrystus przygarnął was - ku chwale Boga. Albowiem Chrystus - mówię - stał się sługą obrzezanych, dla okazania wierności Boga i potwierdzenia przez to obietnic danych ojcom oraz po to, żeby poganie za okazane sobie miłosierdzie uwielbili Boga, jak napisano:

17 W. Winter, Gościna, kol. 394. Motywacja podobna do tej, która występuje w Rz 15,7-12, jest widoczna w Liście do Efezjan. Paweł przypomina wiernym pochodzącym z pogan, że „stali się bliscy przez krew Chrystusa” (Ef 2,13), nie są już „obcymi i przychodniami”

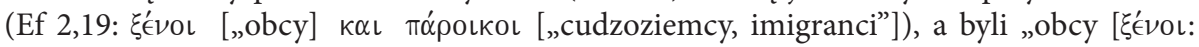
"obcy" = „nie-Żydzi”, „cudzoziemcy”] wobec społeczności Izraela” (Ef 2,12). 
Dlatego oddawać Ci będę cześć między poganami i śpiewać imieniu Twojemu.

Znów mówi Pismo:

Weselcie się, poganie, wraz z ludem Jego!

I znowu:

Chwalcie Pana, wszyscy poganie.

Niech Go uwielbiaja wszystkie narody!

Nadto także Izajasz powiada:

Przyjdzie potomek Jessego,

powstanie Ten, który ma rządzić poganami,

w Nim poganie pokładać będa nadzieję."

W Rz 15,7-12 Paweł zwraca się do chrześcijan pochodzących z pogan. Zaproszenie pogan do wiary jest aktem miłosierdzia ze strony Boga. „Należy się” im jeszcze mniej, niż Żydom, skoro Chrystus był Żydem (Rz 15,8: „sługą obrzezanych”; 15,12: „potomkiem Jessego”). Tym niemniej taki plan Boga jest zapowiedziany w Torze (Rz 15,10; por. Pwt 32,43), u Proroków (Rz 15,9.12; por. 2 Sm 22,50; Iz 11,10) i w Pismach (Rz 15,11; por. Ps 18,50; 117,1).

\subsection{Rozwaga (rozum: voûs; $R z 12,1-2$ )}

Z drugiej strony, gościnność nie jest wyjęta spod podstawowego prawa opisanego w Rz 12,1-2, które jest streszczeniem fundamentalnej zasady teologii moralnej św. Pawła: chrześcijanie powinni się kierować rozumem, rozwagą, we wszystkim, co czynią. Wcielanie Ewangelii w życie, której elementem jest także wymóg gościnności (zob. Rz 15,7), dokonuje się przez rozumne decyzje. Rz 12,1-2 stanowi sformułowanie fundamentalnej zasady streszczającej podstawowe proncipium teologii moralnej św. Pawła. Istotę tej zasady tak streszcza Ugo Vanni: „Chrześcijanin posiada en bloc dar poznania woli Bożej, gdyż posiada już dar Chrystusa, który jest mistrzem i prawdą. Ten dar jest dany «w stanie surowym». Dar Chrystusa musi zostać odniesiony do praktyki życiowej, musi być aktywowany, przepracowany pod wpływem Ducha [...] Konieczne jest zaangażowanie, uwaga, refleksja, rozeznanie, ocena, gdyż - w przeciwnym wypadku - pozostanie się na etapie woli Bożej prowizorycznej"18.

$18 \mathrm{U}$. Vanni, Il comportamento del cristiano nella vita individuale e sociale. La parte parenetica della lettera ai Romani, s. 72-73. 


\subsubsection{Kontekst i odniesienie do problematyki gościnności}

Głównym tematem Listu do Rzymian jest Ewangelia. Dwie części listu składają się na schemat, w którym Paweł idzie od „indykatywu” (Rz 1-11) do ,imperatywu” (Rz 12-15) ${ }^{19}$. W drugiej części listu ${ }^{20}$ Paweł wskazuje na sposób „przekładania" Ewangelii na realia życiowe, zgodnie z poniższym schematem:

\begin{tabular}{lc} 
INDYKATYW & \multicolumn{1}{l}{ IMPERATYW } \\
\hline$\underline{\mathbf{1 , 1 6}-\mathbf{1 7}} \longrightarrow \underline{\mathbf{1 2 , 1 - 2}}$ \\
TEZA LISTU & REGUŁA \\
& NADRZĘDNA \\
$\mathbf{1 , 1 8 - 1 1 , 3 6 :}$ & \\
rozwinięcie & $\mathbf{1 2 , 3 - 1 5 , 1 3 :}$ \\
tezy & aplikacja \\
& reguły nadrzędnej
\end{tabular}

„Indykatyw” przygotowuje sformułowanie „imperatywu”. Obie części Listu do Rzymian rozpoczynają się od zdania programowego dla dalszego tekstu: od tezy (Rz 1,16-17) i od reguły wskazujących na sposób „przekładania” Ewangelii o usprawiedliwieniu przez wiarę na realia życiowe (Rz 12,1-2).

Aby uchwycić specyfikę myślenia św. Pawła ukazanego w Rz 12,1-2, warto porównać je $\mathrm{z}$ podejściem widocznym $\mathrm{w}$ Talmudzie. W tradycji rabinistycznej, która zaowocowała powstaniem komentarza do Tory w postaci dwóch Talmudów (zwanych Torą ustną), znajduje się 613 zakazów i nakazów, które stanowią rodzaj szczegółowego przewodnika postępowania w konkretnych sytuacjach życiowych. Jako przykład można podać tekst z Miszna Szabbat 7,2 będący komentarzem do przykazania biblijnego: „Pamiętaj, aby dzień święty święcić" (zob. Wj 20,8-11). Co oznacza według tradycji talmudycznej

19 „Corpus” Listu do Rzymian jest poprzedzony wstępem epistolarnym (Rz 1,1-15). W Rz 15,14-16,27 jest zawarte zakończenie listu.

20 Dwa zdania zawarte w Rz 12,1-2 są konsekwencją wykładu dokonanego przez Pawła w tekście wcześniejszym, na co wskazuje partykuła ouv. Wielki komentator Rz, K. Barth (idem, Breve commentario allepistola ai Romani, s. 165nn), nadaje tekstowi zawartemu w Rz 12,1-15,13 tytuł: „Ewangelia wśród chrześcijan”. 
„święcenie szabatu”? Czytamy: „Jest 39 kategorii prac zakazanych w szabat: 1. siać, 2. orać, 3. żąć, 4. wiązać snopki, 5. młócić, 6. przewiewać, 7. oczyszczać owoce, 8. mielić, 9. przesiewać, 10. mieszać ciasto, 11. gotować, 12. strzyc, 13. prać tkaninę, 14. czesać wełnę, 15. farbować wełnę, 16. prząść, 17. przygotować krosna, 18. robić pętlę, 19. tkać, 20. rozdzielać dwie nici, 21. zawiązywać węzeł, 22. rozwiązywać węzeł, 23. szyć, 24. rozdzierać, 25. chwytać kozła w pułapkę, 26. zarzynać kozła, 27. obdzierać kozła ze skóry, 28. garbować skórę, 29. prać ją, 30. farbować skórę, 31. kroić kozła, 32. pisać, 33. zmazywać, 34. budować, 35. burzyć, 36. gasić ogień, 37. rozpalać ogień, 38. wykonywać ostatnie uderzenie młotkiem, 39. przenosić przedmioty z jednego ogrodzenia do drugiego ${ }^{21}$ ". Jest to droga tych, którzy w każdej szczegółowej sytuacji będą szukali gotowej odpowiedzi spisanej bądź przekazanej ustnie przez jakiś zewnętrzny autorytet (wokół tekstów talmudycznych narastały jeszcze przez wieki reguły aktualizujące tekst ${ }^{22}$ ).

Św. Paweł wybiera inną drogę, wskazując w Rz 12,1-2 jedną regułę, która ma porządkować całe życie chrześcijanina: chrześcijanin powinien kierować się rozumem. Na trud intelektualny wskazują wyrażenia: „rozumna służba Boża”, „odnawianie umysłu”, „umieć rozpoznać”. Jak wiemy z wcześniejszego wykładu zawartego w Rz 1,18nn, nie chodzi o rozum „naturalny”, bo ten ma ogląd rzeczywistości zaciemniony przez grzech, ale o umysł wsparty mocą Ducha Świętego (zob. Rz 8). Duch Święty, zamieszkując w chrześcijaninie, sprawia, że „umysł” jest zdolny do rozpoznawania woli Bożej.

„Złota reguła” zapisana w Rz 12,1-2 dotyczy wszystkich obszarów życia, z których niektóre Paweł wymienia w Rz 12,2-15,13. Programowemu zdaniu zawartemu w Rz 12,1-2 jest podporządkowany ciąg perykop: a) 12,3-8: „Niech nikt nie ma o sobie wyższego mniemania, niż należy”; b) 12,9-21: „Miłość niech będzie bez obłudy”; c) 13,1-7: „Należy się poddać (władzy)... ze względu na sumienie”; d) 13,8-10: „Kto miłuje bliźniego, wypełnił Prawo”; e) 13,11-14: „A zwłaszcza rozumiejcie chwilę obecną”; f) 14,1-23: „A swoje własne przekonanie zachowaj dla siebie przed Bogiem”; g) 15,1-6: „Powinniśmy znosić słabości tych, którzy są słabi”; h) 15,7-12: „Przygarniajcie siebie nawzajem”. Logika Rz 12,1-15,12 zmierza do wniosku zapisanego w Rz 15,13,

21 J.J. Petuchowski, La Voce del Sinai, s. 67-68, przytacza tekst Mishnah Shabbath 7,2 (tłum. z włoskiego: GR).

22 Zob. komentarz do Mishnah Shabbath 7,2 na portalu internetowym „The 614th Commandment Society, North Hollywood, California". 
w którym św. Paweł wskazuje, że owocem rozumnego życia chrześcijan (życia zgodnego z reguła zapisaną w Rz 12,1-2) jest radość, pokój i nadzieja ${ }^{23}$.

Wskazanie zawarte w Rz 12,9 („Miłość niech będzie bez obłudy”), któremu podporządkowana jest problematyka gościnności ( $\mathrm{Rz} 12,13)$, musi być interpretowane w świetle normy zapisanej w Rz 12,1-2. Kierowanie się wiarą nie oznacza pójścia za bezrozumną intuicją, ale domaga się konkretyzacji poprzez wysiłek intelektualny. Zbawienie przez samą (!) wiarę nie sprzeciwia się określeniu konkretnych „uczynków”, które są owocem przyjęcia Ewangelii. Paweł jawi się jako praktyczny duszpasterz, który wie, w jaki sposób normy Ewangelii trzeba przełożyć na życiowe realia.

\subsubsection{Przekład i komentarz}

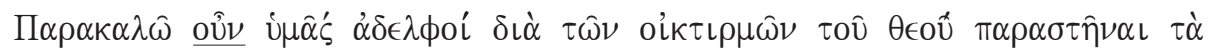

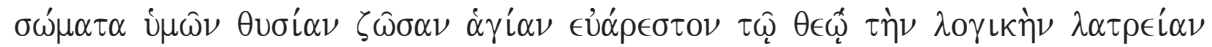
ú $\mu \hat{\omega} \nu \cdot$

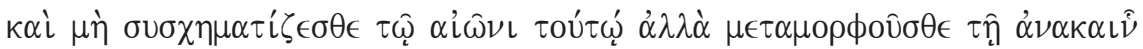

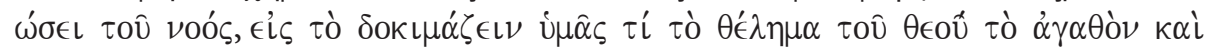

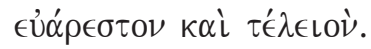

„Błagam więc was, bracia, przez miłosierdzie Boże, abyście dawali ${ }^{24}$ ciała swoje (= siebie) na ofiarę żywą, świętą, Bogu przyjemną, będącą waszym kultem logicznym (=odpowiadającym waszej rozumnej naturze).

23 Współzależność Rz 12,1-2 i kolejnych perykop należących do części parenetycznej listu, ilustruje poniższy schemat:

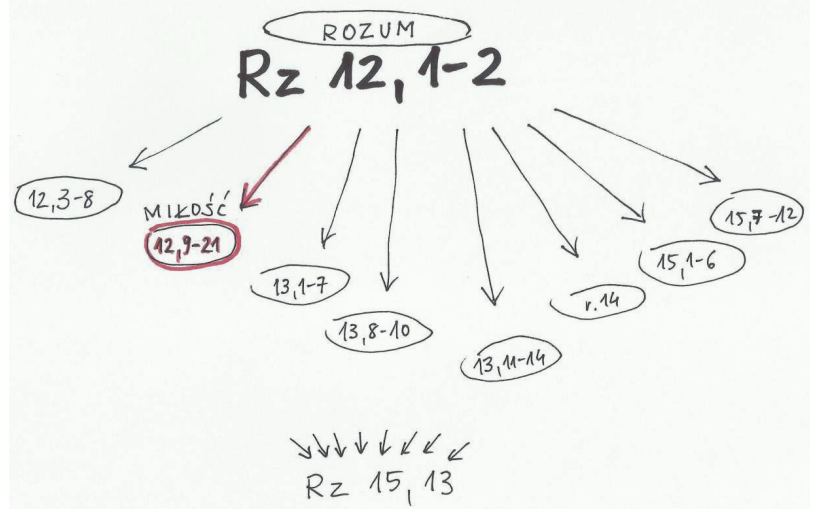

24 Aor. inf. $\pi \alpha \rho \alpha-\sigma \tau \eta \hat{\sigma \alpha \iota}$ od $\pi \alpha \rho-\hat{\imath} \sigma \tau \eta \mu \iota$ wskazuje, że autorowi tekstu nie chodziło o określenie aspektu czynności: czy była to czynność dokonana, czy niedokonana. Możliwe 
Nie bierzcie więc wzoru $\mathrm{z}$ tego świata, lecz przemieniajcie się przez odnawianie umysłu, abyście umieli rozpoznać, jaka jest wola Boża: co jest dobre, co Bogu przyjemne i co doskonałe".

$\mathrm{Rz}$ 12,1. Błagam więc. Czasownik $\pi \alpha \rho \alpha \kappa \alpha \lambda \hat{\omega}$ opisuje usilną prośbę (por. Rz 15,30; 16, 17; 1 Kor 1,10; 4,16; 2 Kor 2,8; 10,1; Flp 4,2; Flm 10). Partykuła oûv wskazuje, że tekst rozpoczynający się od Rz 12,1 jest kontynuacją wykładu zawartego w poprzedniej sekcji tekstu. „Chrześcijańska moralność jest odpowiedzią na miłosierdzie Boże opisane w poprzednich rozdziałach” (J. A. Fitzmyer $)^{25}$.

was, bracia. Paweł zwraca się do całej wspólnoty w Rzymie. Taki jest sens określenia „bracia”. Wyznawcy Chrystusa nazywali siebie „braćmi”, „uczniami”, „świętymi”, a w Antiochii „po raz pierwszy nazwano uczniów chrześcijanami” (Dz 11,26). Relacja Pawła do „braci” zakłada jego autorytet apostolski.

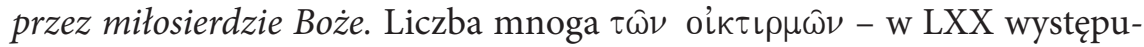
je w miejsce hebr. pl. rahamim (aram. rahmin) ${ }^{26}$. Wszystkie rozumne decyzje

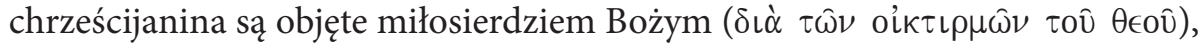
także te, które okazałyby się błędne. Warto zauważyć, jak wielkim zaufaniem Paweł darzy człowieka!

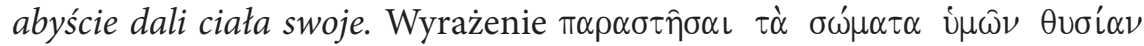

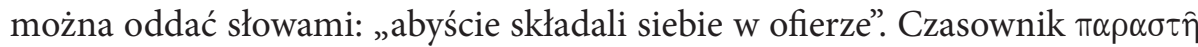
$\sigma \alpha \iota$ określa akt oddania czegoś do czyjejś dyspozycji, w tym także akt oddania czegoś w ofierze (tak: Józef, Ant. 4.6.4\$113; Lucjan; De sacrificiis 13). Przedmiotem pouczeń Pawła jest życie ludzkie osadzone w konkretnym czasie i przestrzeni, we wszystkich jego aspektach - taki jest sens terminu $\sigma \omega \hat{\omega} \mu \alpha$ (por. Rz 6,13: „Nie oddawajcie też członków waszych jako broń nieprawości na służbę grzechowi, ale oddajcie się na służbę Bogu jako ci, którzy ze śmierci przeszli do życia, i członki wasze oddajcie jako broń sprawiedliwości na służbę Bogu”.) „Podczas gdy w tradycji żydowskiej ofiara obejmowała zabicie tego, co było ofiarowane, Paweł używa tego słowa figuratywnie w odniesieniu do chrześcijańskiego życia i działania"27. Tym samym, Paweł przełamuje podział na sferę „sacrum” i „profanum”.

jest tłumaczenie: „dali / dawali”. Lepsze jest tłumaczenie: „dawali”, gdyż na aspekt „ciągły” czynności wskazuje presens (pass. Imptv.) $\mu \epsilon \tau \alpha \mu о \rho \phi o v ̂ \sigma \theta \epsilon$.

25 J.A. Fitzmyer, Romans. A New Translation with Introduction and Commentary, s. 639 .

26 Ibidem.

27 Ibidem. 
na ofiarę żywą, świętą, Bogu przyjemna, będąca kultem odpowiadającym waszej rozumnej naturze. Całe życie chrześcijańskie jest ofiarą ( $\theta v \sigma i ́ \alpha)$ „żywą, świętą, Bogu przyjemną" - jak ofiary składane w świątyni jerozolimskiej. Jest jednak ofiarą daleko doskonalszą przez fakt rozumności, będąc „kultem logicznym”. Zwrot: $\lambda$ oүıкทे $\lambda \alpha \tau \rho \in i \alpha$ można przetłumaczyć jako „kult logiczny, rozumny”, lub „kult duchowy”. To pierwsze tłumaczenie lepiej wskazuje na to, że „globalna sakralność nadaje życiu sens, «logikę», co jest spojrzeniem specyficznie greckim" (U. Vanni ${ }^{28}$ ). Chodzi o kult mający źrodło w $\lambda$ ó үos, czyli - wraz z vous i $\pi \nu \cup \hat{u} \mu \alpha$ - w najszlachetniejszej sferze ludzkiego jestestwa, odróżniającej człowieka od irracjonalnych zwierzą ${ }^{29}$. Przymiotnik $\lambda$ oүıкós określa apekt racjonalny działania, w przeciwieństwie do działania mechanicznego, bezrefleksyjnego, a także na aspekt duchowy. Określenie: „kult logiczny” oznacza taki kult, w którym jest zaangażowany umysł i duch, w przeciwieństwie do kultycznych rytów zewnętrznych ${ }^{30}$.

$\mathrm{Rz} 12,2$. Co oznacza „kult odpowiadający rozumnej naturze” człowieka ( $\lambda \hat{\mathrm{o}}$

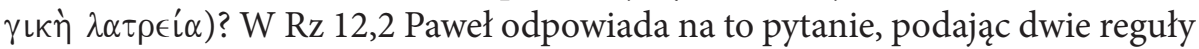
wykonawcze: „Nie bierzcie więc wzoru z tego świata” (reguła negatywna); „lecz przemieniajcie się przez odnawianie umysłu, abyście umieli rozpoznać, jaka jest wola Boża: co jest dobre, co Bogu przyjemne i co doskonałe" (reguła pozytywna).

Nie bierzcie więc wzoru z tego świata. Wyrażenie "ten świat” jest nawiązaniem do żydowskiego rozróżnienia między „tym światem/eonem” i „przyszłym światem/eonem". W rozumieniu chrześcijańskim Królestwo Boże już nastało od momentu pierwszego przyjścia Chrystusa, ale jeszcze nie osiągnęło ostatecznego spełnienia i aż do wspólistnieje ono ze starym porządkiem ${ }^{31}$. Różnicę

28 U. Vanni, op. cit., s. 69.

29 Zob. J. A. Fitzmyer, op. cit., s. 640. Na temat rozwoju pojmowania $\lambda$ ó ${ }^{\circ} \varsigma \mathrm{w}$ filozofii

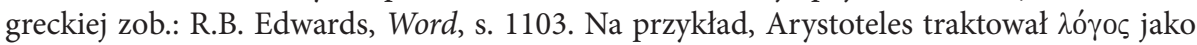
cechę rozumu posiadaną przez człowieka, odróżniającą go od zwierząt, która polega na uzdolnieniu człowieka do wyrażania siebie przez mowę (Pol. i.1.1253a).

30 Zob. M. Zerwick, M. Grosvenor, A grammatical Analysis of the Greek New Testa-

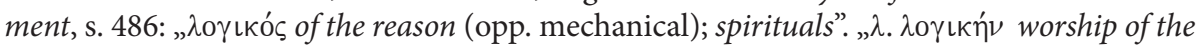
mind and and spirit opp. external rites".

31 Zob. O. Cullmann, Cristo e il tempo (oryg. Christus und die Zeit, Zürich 1946). Żyjemy w czasie między pierwszym przyjściem Chrystusa a Paruzją, niejako na granicy czasów. W związku z tym może jawić się pytanie, które następująco ujął R. Bultmann: „Kann der Glaubende seine Gegenwart als jenes «Zwischen» verstehen, wenn sich dieses «Zwischen» immer weiter ausdehnt, schließlich auf bald 2000 Jahre?” (R. Bultmann, Der Mensch zwischen den Zeiten nach dem Neuen Testament, s. 36). R. Bultmann przenosi odpowiedź na to pytanie na płaszczyznę egzystencjalną, zauważając, że "granica czasów” przebiega przez 
w pojmowaniu czasu w apokaliptyce żydowskiej i w apokaliptyce chrześcijańskiej obrazują poniższe schematy:

1) Apokaliptyka żydowska:

\section{Centrum}

historii

\section{(w przyszłości):}

„eon obecny” interwencja ,eon przyszły”

(np. A.D.2017)

Boga

panowanie zła

panowanie dobra

2) Apokaliptyka chrześcijańska:

\section{Centrum}

historii

(w przeszłości):

Wcielenie

$$
\text { (,już”) czas Kościoła (,jeszcze nie") Paruzja }
$$

(np. A.D. 2017)

\section{$!$}

zwycięstwo dobra jest przesądzone, ale jeszcze działaja moce zła

Według nauki św. Pawła „przemija postać tego świata” (1 Kor 7,31). „Przyszły świat/eon” już się rozpoczął (zob. 1 Kor 10,11): w Chrystusie, który „wyrwał nas z obecnego złego świata” (Ga 1,4) i „za sprawą Ducha Pańskiego” (2 Kor 3,18). Rozwój historii zbawienia zależy od dynamicznej relacji Boga i Jego ludu. Bóg może skrócić lub wydłużyć jej poszczególne etapy. „Rozumienie chwili

ludzką egzystencję. W każdym człowieku realizuje się „stary” i „nowy” porządek. Człowiek należy do „tego świata/eonu” (żyje w „starym eonie”), jeśli kroczy drogą grzechu. Żyje $\mathrm{w}$ „nowym eonie”, jeśli idzie za Chrystusem. 
obecnej” (Rz 13,11) nie jest szukaniem odpowiedzi na pytanie: „kiedy i co?”, ale na pytanie: „kto?”, gdyż wszystko dokonuje się „w Chrystusie”.

lecz przemieniajcie się przez odnawianie umysłu. Przemienianie się zakłada pomoc łaski Bożej i Ducha Świętego (por. Rz 8,12-14). Dotyczy sfery życia ludzkiego obejmującego działanie rozumu i sferę wolitywną (decyzje moralne) człowieka (voûs).

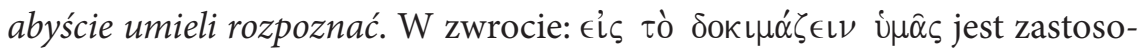

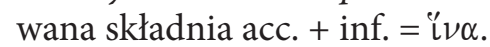

jaka jest wola Boża: co jest dobre, co Bogu przyjemne i co doskonałe. Istotą $\lambda \hat{\delta}$

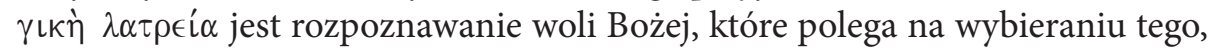
„co jest dobre, co Bogu przyjemne i co doskonałe”.

\subsection{Uwarunkowania społeczno-polityczne (Rz 13,1-7; 1 Kor 6,1-11)}

Indywidualne decyzje podejmowane przez chrześcijan muszą uwzględniać kontekst społeczno-polityczny, który św. Paweł zarysowuje w dwóch tekstach:

a) Rz 13,1-7 (zob. Rz 13,1: „Niech każdy będzie poddany władzom, sprawującym rządy nad innymi”);

b) 1 Kor 6,1-11 (problem współistnienia porządku prawa „świeckiego” i prawa Ewangelii).

\subsubsection{Chrześcijanin w relacji do państwa (Rz 13,1-7)}

Perykopa rozpoczyna się od zdania: „Każdy niech będzie poddany władzom, sprawującym rządy nad innymi” (Rz 13,1). Zdania tego nie można jednak odrywać od kontekstu bliższego ( $\mathrm{Rz} 13,1-7)$ i dalszego (cała sekcja Rz 12,1-15,13), a zwłaszcza od programowej zasady zapisanej w Rz 12,1-2, która wskazuje, że nic nie zwalnia chrześcijanina od rozumnej oceny rzeczywistości, w której żyje. Dotyczy to także życia chrześcijanina w państwie. Paweł pisze w Rz 13,1-7 o władzy, którą ocenia jako sprawiedliwą. Jak wynika z Rz 13,3-5, chodzi o władzę, która za dobre wynagradza, a za złe karze (jest to jedyne kryterium wskazane przez Pawła; państwo „wyznaniowe” nie jest dla Pawła żadnym ideałem!). Wobec takiej władzy chrześcijanin zaciąga zobowiązania „nie tylko ze względu na karę, ale ze względu na sumienie” (Rz 13,5), którymi są: płacenie podatku, cła, uległość, cześć ( $\mathrm{Rz} 13,6-7)$. W Rz 13,1-7 Paweł nie rozważa sytuacji, w której chrześcijanin oceniłby władzę jako niesprawiedliwą. Perykopę tę należy czytać jednak w kontekście całego NT, w tym, w kontekście Ap. Jeśli chrześcijanin, kierując się rozumną oceną sytuacji, stwierdziłby, że władza jest niesprawiedliwa (takiej oceny dokonał autor Ap), to jest zobowiązany do obywatelskiego nieposłuszeństwa, a nie do podległości wobec władzy. 


\subsubsection{Chrześcijanin i „wyższa sprawiedliwość” (1 Kor 6,1-11)}

Perykopa zaczyna się od pytania: „Czy odważy się ktoś z was, gdy zdarzy się nieporozumienie z drugim, szukać sprawiedliwości u niesprawiedliwych, zamiast u świętych?” (1 Kor 6,1). W pytaniu tym jest zawarta sugestia, aby spierający się między sobą chrześcijanie korynccy poddawali się osądowi autorytetów kościelnych („świętych”), zamiast szukać arbitrażu w sądach państwowych („u niesprawiedliwych”). Najlepiej zaś, aby w ogóle nie było między nimi sporów (por. 1 Kor 6,7). Sytuacja opisana w tej perykopie straciła dla nas aktualność. Poddawanie się arbitrażowi sądów państwowych jest dziś ogólną praktyką i trudno oczekiwać, aby o wszystkim rozstrzygały sądy kościelne. Nie stracił natomiast aktualności problem, który stwarza współistnienia dwóch porządków prawnych, w których żyją chrześcijanie. Podlegamy regułom stanowionym w państwie, a równocześnie jesteśmy zobowiązani do kierowania się Ewangelią. Wyznacznikiem decyzji chrześcijanina musi być „wyższa sprawiedliwość”, a nie mądrość tego świata.

W obszarze krzywd osobistych powinna obowiązywać postawa opisana przez św. Pawła w pytaniu: „Czemuż nie znosicie niesprawiedliwości? Czemuż nie ponosicie raczej szkody" (1 Kor 6,7). W odniesieniu do spraw regulowanych przez władze państwowe, potrzebna jest ciągła konfrontacja $z$ Ewangelią. Możliwy jest wniosek, że chrześcijanie powinni do porządku istniejącego dzięki decyzjom państwa wprowadzać opcję na rzecz „wyższej sprawiedliwości”. Dotyczy to także stosunku do uchodźców. Reguły ich przyjmowania ustalane są przez decyzje władz państwowych. W granicach wyznaczonych przez władzę chrześcijanie powinni stosować reguły Ewangelii. Kierowanie się Ewangelią można opisać jako „transcendowanie” reguł ustalanych w „tym świecie”. Dotyczy to relacji między członkami Kościoła, ale ma także przełożenie na relacje z „Wszystkimi ludźmi” (Rz 12,17; por. Prz 3,4 LXX). Aspekty takiego „transcendowania” reguł tego świata są opisane przez Pawła w Rz 12,3-15,13:

- 13,8-10. Z Rz 13,1-7 wynikało, że szukanie tego, "co doskonałe" (do czego wzywał Paweł w Rz 12,2!) w życiu obywatelskim, oznacza dla chrześcijan lojalne spełnianie obowiązków wobec państwa. W Rz 13,8-10 Paweł dopowiada, że w relacjach międzyludzkich spełnianie obowiązków, to za mało. Szukanie tego, „co doskonałe” w stosunkach z bliźnimi oznacza bowiem kierowanie się miłością - ona jest doskonałym wypełnieniem Prawa $^{32}$. Zamiast zasady parytetu dóbr wymienianych przez nas z bliź-

32 Biblią młodego Kościoła był Stary Testament. Na tym tle musiało pojawić się pytanie: jak chrześcijanin ma wypełnić Prawo? W Rz 3,31 Paweł stwierdził, że przez wiarę nie obala Prawa, tylko Prawo właściwie ustawia. W Rz 13,8-10 Paweł daje odpowiedź na to 
nimi, obowiązuje zasada nieproporcjonalności: nasza odpowiedź ma zawsze „transcendować poprawność” w stosunkach z ludźmi. Mamy dawać więcej, niż otrzymujemy od innych. Doskonałość mierzy się wyczuciem swoistego „długu”: kto więcej tego długu spłaca, ten jest doskonalszy.

- Rz 13,11-14. Trzeba rozumieć chwilę obecną (13,11), tzn. rozumieć, że zaczął się czas eschatologiczny i że zbawienie jest coraz bliżej $(13,11)$. Ten czas domaga się podejmowania radykalnych decyzji: odrzucenia uczynków ciemności $(13,12)$, przyzwoitego życia $(13,13)$, naśladowania Jezusa Chrystusa $(13,14)$.

- Rz 15,1-6. Z Rz 13,8-10 wynikało, że mamy dawać innym jak najwięcej według miary miłości. W Rz 15,1-6 Paweł dopowiada, że nie należy zbyt dużo oczekiwać od innych. Kościół nie jest wspólnotą składającą się z samych ideałów. Chrześcijanie „mocni” powinni stwarzać we wspólnocie przestrzeń dla „słabych”. Wzorem cierpliwości jest sam Chrystus.

\section{Aktualizacja orędzia św. Pawła na temat gościnności: problem uchodźców}

Aktualizacja nie jest „dodatkiem do egzegezy”, ale jest integralną (i najbardziej ryzykowną!) częścią analizy tekstu biblijnego. „Studium Pisma świętego jest zamknięte dopiero wtedy, gdy prowadzi do zrozumienia sensu egzystencjalnego Pisma; wtedy Pismo staje się «Słowem Bożym» i «źródłem życia duchowego"33. Kierując się tą wskazówką metodologiczną, w ostatnim punkcie niniejszego artykułu odniesiemy naukę św. Pawła o gościnności do jednego z najbardziej aktualnych problemów, jakim jest relacja chrześcijan do uchodźców.

Wielkoduszność, czy rozwaga? Odpowiedź na to pytanie jest bardzo jasna. Chrześcijanin ma realizować opcję na rzecz wielkoduszności. Wyraża to następująco Papież Franciszek: „Darmo otrzymaliśmy, darmo dajemy. Jesteśmy wezwani do tego, by służyć Jezusowi ukrzyżowanemu w każdej osobie wykluczonej. Dotknąć ciała Chrystusa w tym, kto jest wykluczony, głodny, spragniony, nagi, w więzieniu, chory, prześladowany, kto jest uchodźcą. To tam znajdziemy naszego Boga, dotykamy Pana” ${ }^{4}$. „Pamiętajmy zawsze o słowach św. Jana od Krzyża: «Pod wieczór życia będziemy sądzeni z miłości»" ${ }^{35}$.

pytanie, co oznacza w praktyce „Prawo właściwie ustawione”. Ideał doskonałości chrześcijańskiej określa miłość bliźniego; ona jest właściwym wypełnieniem Prawa ST.

33 W. Egger, Metodologia del Nuovo Testamento, s. 225.

34 Franciszek, Miłosierdzie to imię Boga. Rozmowa $z$ Andrea Torniellim, s. 131.

35 Ibidem, s. 132. 
Stosunek Papieża Franciszka do uchodźców jest niezrozumiały dla znakomitego publicysty Pawła Lisickiego. W wypowiedzi opublikowanej na portalu Wirtualna Polska ${ }^{36}$ publicysta ten opisuje następującą sytuację: „W sobotę (16.04.2016 r. - przyp. GR) papież Franciszek przybył na grecką wyspę Lesbos, gdzie wraz z prawosławnym patriarchą ekumenicznym Bartłomiejem i arcybiskupem Aten i Grecji Hieronimem zaapelował o pokój. Ojciec Święty odwiedził również obóz uchodźców. Powiedział, że w każdym ze spotkanych uciekinierów należy widzieć człowieka, a nie problem statystyczny. Na znak swojego zaangażowania w rozwiązanie kwestii imigrantów zaprosił trzy rodziny uchodźców, w sumie dwanaście osób, do Watykanu. Wszyscy są muzułmanami z Syrii i Iraku. Jak łatwo przewidzieć, ten gest papieża spotkał się z entuzjastycznym przyjęciem światowych mediów”.

Publicysta dodaje swoją interpretację postępowania papieża Franciszka: „Niektórzy uznali, że w ten sposób Franciszek postanowił obudzić sumienia Europejczyków, inni widzieli w znaku prawdziwie ewangeliczną naukę miłości. Ochom i oklaskom nie było końca. Przykro mi, ale nie jestem w stanie ani się tym gestem zachwycić, ani dopatrywać się w nim znaku prawdziwego humanitaryzmu. Tak jak już wcześniej starałem się to pokazać w książce «Dżihad i samozagłada Zachodu» kolejne gesty papieskie w stosunku do muzułmanów są oznaką słabości i przyczyniają się do chaosu”.

P. Lisicki poprzedza kolejny akapit swej wypowiedzi podtytułem: „Utopia Franciszka” i pisze w nim: „Najwyraźniej Franciszek chciał pokazać dwie rzeczy. Po pierwsze, że właściwą odpowiedzią na kryzys imigracyjny powinno być otwieranie granic poszczególnych państw europejskich, po drugie, że nie wolno, przyjmując uchodźców, kierować się ich religią. Przesłanie to zdaje się być klasycznym przejawem myślenia utopijnego i abstrakcyjnego, tak typowego dla współczesnej zachodniej lewicy. Zamiast dawać przykład roztropności, uczy polityków europejskich braku odpowiedzialności”.

Na podstawie przesłanek zawartych w listach św. Pawła można łatwo odnieść się do opinii publicysty. Jego ocena, aczkolwiek dokonana z troski o przyszłość Europy, nie uwzględnia istnienia dwóch porządków prawa, którym podlegają chrześcijanie:

- Z jednej strony, podlegamy prawu państwowemu, czyli regułom ustalanym przez polityków w ramach gry demokratycznej. Chrześcijanie nie są jedynymi uczestnikami gry demokratycznej (NB. Dla chrześcijan nie jest żadnym ideałem „państwo wyznaniowe”, w którym miejsce prawa państwowego zajęłaby Ewangelia - coś na podobieństwo szariatu. Trudno sobie w tej roli wyobrazić Papieża).

36 P. Lisicki, Dla papieża Franciszka liczą się tylko dokumenty. 
- Z drugiej strony, obowiązkiem chrześcijanina (także Papieża) jest „transcendować" reguły ustalone przez polityków, wprowadzając Ewangelię w przyjęte przez nich rozwiązania.

Nie ma to nic wspólnego $\mathrm{z}$ „utopią”. Słowa i gesty papieża są nie tyle - jak to określił publicysta - utopią, ile raczej trzeba je zinterpretować jako "gesty prorockie".

\section{Zakończenie: reguły gościnności na Bliskim Wschodzie}

Niektóre teksty św. Pawła są ilustracją reguł gościnności panujących na Bliskim Wschodzie. Jak zauważa B. J. Malina, „na obszarze starożytnego Bliskiego Wschodu gościnność była ściśle związana ze zwyczajami i praktykami, których przestrzegania oczekiwano od wszystkich. Ze starożytnymi obyczajami dotyczącymi gościnności było podobnie jak $\mathrm{z}$ tańcem charakteryzującym się precyzyjnym układem choreograficznym, w którym każda z osób musi odgrywać swoją rolę lub zrezygnować z uczestniczenia w nim, by wszystkiego nie popsuć. Ten, kto lekceważył obowiązujące zwyczaje, zawsze czynił to na własny rachunek"37.

Inne reguły panowały przy goszczeniu rodziny i przyjaciól, a inne - przy przyjmowaniu obcych. Przyjęcie w gościnę obcych miało trzy fazy, w które wpisują się niektóre teksty św. Pawła:

1) Badanie obcego: Sposobem badania było między innymi poproszenie gościa o zabranie głosu (Dz 13,14-15). Mógł on też być wyposażony w listy polecające (Rz 16,3-16; 1 Tes 5,12-13).

2) Przemiana obcego w gościa: gość oddawał się pod opiekę gospodarza (1 Kor 9,4). Goście mieli obowiązek zaniechania wzajemnej wrogości (na tym tle należy spojrzeć na problem Pawła opisany w 1 Kor 11,17-34).

3) Ponowna przemiana gościa w obcego: Jeśli gość opuszczał dom gospodarza jako przyjaciel, rozsławiał jego imię (1 Tes 1,9; Flp 4,16) ${ }^{38}$.

\section{Bibliografia}

Barbaglio G., Paolo di Tarso e le origini cristiane, Assisi 1989.

Barth K., Breve commentario allepistola ai Romani, Brescia 1990.

37 B. J. Malina, Gościnność, s. 354.

38 Ibidem, s. 355-356. 
Bultmann R., Der Mensch zwischen den Zeiten nach dem Neuen Testament, w: Glauben und Vesrtehen, t. III, Tübingen 1984, s. 35-39.

Cullmann O., Cristo e il tempo. La concezione del tempo e della storia nel cristianesimo primitivo, Bologna 1980.

Edwards R.B., Word, w: The International Standard Bible Encyclopedia, vol. IV, red. G.W. Bromiley, Grand Rapids 1988, s. 1101-1107.

Egger W., Metodologia del Nuovo Testamento. Introduzione allo studio scientifico del Nuovo Testamento, Bologna 1989.

Fitzmyer J.A., Romans. A New Translation with Introduction and Commentary, New York, London, Toronto, Sydney, Auckland 1993.

Franciszek, Miłosierdzie to imię Boga. Rozmowa z Andrea Torniellim, Kraków 2016.

Lisicki P., Dla papieża Franciszka licza się tylko dokumenty, Portal internetowy „Wirtualna Polska”, publikacja z 18.04.2016 r.

Malina B. J., Gościnność, w: Encyklopedia biblijna, red. P.J. Achtemeier, Warszawa 1999, s. 354-356.

Ortiz P., List do Filipian, w: Międzynarodowy komentarz do Pisma Świętego. Komentarz katolicki i ekumeniczny na XXI wiek, red. W.R. Farmer, Warszawa 2000, s. 1537-1545.

Petuchowski J.J., La Voce del Sinai. Letture rabbiniche sui Dieci Comandamenti dagli scritti ebraici e aramaici, Napoli1985.

Rafiński G., Rozum jako źródło wartości moralnej czynu ludzkiego w Liście św. Pawła do Rzymian, w: Miłość jest z Boga. Wokót zagadnień biblijno-moralnych. Studium ofiarowane ks. prof. dr. hab. Janowi Łachowi, red. M. Wojciechowski, Warszawa 1997, s. 335-357.

Romaniuk K., List do Rzymian. Wstęp - przekład z oryginału. Komentarz, PoznańWarszawa 1978.

Smit J., The Leter of Paul to the Galatians. A Deliberative Speech, New Testament Studies 35 (1989) s. 1-26.

Szamocki G., Święty Paweł rzemieślnik, w: Życie, apostolat i dziedzictwo Pawła z Tarsu, red. W. Gajewski, J. Iluk, I. Milewski, H. Pietras, G. Szamocki, (Christianitas Antiqua, vol. III, wyd. UG), Gdańsk 2010, s. 64-74.

Vanni U., Il comportamento del cristiano nella vita individuale e sociale. La parte parenetica della lettera ai Romani, w: Attualità della lettera ai Romani, red. P. Rossano, R. Penna, U. Vanni, A. Rigobello, E. Bianchi, R. Di Segni, Roma 1989, s. 67-78.

Winter W., Gościna, w: Praktyczny słownik biblijny, red. A. Grabner-Haider, Warszawa 1995, kol. 393-394.

Zerwick M., Grosvenor M., A grammatical Analysis of the Greek New Testament (3 wyd.), Roma 1988. 
